\title{
Article \\ Selective Etching of Sr-Modified and Directionally Solidified Industrial Al-Si Eutectic Alloys for Fabricating Fibrous Eutectic Si
}

\author{
Jianjun Gao ${ }^{1,2} \mathbb{D}$, Wei Gu ${ }^{3}$, Fenfei Zhang ${ }^{3}$, Haibin Geng ${ }^{1, * \mathbb{D}}$, Jianhua Zhong ${ }^{1}$, Ligang Yao ${ }^{1} \mathbb{D}$, Zhilong Zhao $^{4}$ \\ and Junning Wang ${ }^{5}$
}

check for updates

Citation: Gao, J.; Gu, W.; Zhang, F.; Geng, H.; Zhong, J.; Yao, L.; Zhao, Z.; Wang, J. Selective Etching of Sr-Modified and Directionally Solidified Industrial Al-Si Eutectic Alloys for Fabricating Fibrous Eutectic Si. Metals 2021, 11, 1974. https://doi.org/10.3390/met11121974

Academic Editors: Norman Toro, Edelmira Gálvez and Ricardo Jeldres

Received: 14 November 2021

Accepted: 1 December 2021

Published: 8 December 2021

Publisher's Note: MDPI stays neutral with regard to jurisdictional claims in published maps and institutional affiliations.

Copyright: (C) 2021 by the authors. Licensee MDPI, Basel, Switzerland. This article is an open access article distributed under the terms and conditions of the Creative Commons Attribution (CC BY) license (https:/ / creativecommons.org/licenses/by/ $4.0 /)$.
1 School of Mechanical Engineering and Automation, Fuzhou University, Fu Zhou 350108, China; gij410zd@fzu.edu.cn (J.G.); t17003@fzu.edu.cn (J.Z.); ylgyao@fzu.edu.cn (L.Y.)

2 State Key Laboratory of Advanced Welding and Joining, Harbin Institute of Technology, Harbin 150001, China

3 Thinker Agricultural Machinery Co., Ltd., Hu Zhou 313000, China; xgnjgw@163.com (W.G.); zhangfenfei@126.com (F.Z.)

4 School of Mechanical Engineering, Northwestern Polytechnical University, Xi'an 710072, China; zhaolong@nwpu.edu.cn

5 Xi'an Institute of Optics and Precision Mechanics, Chinese Academy of Sciences, Xi'an 710119, China; wjnsun002@163.com

* Correspondence: genghb@fzu.edu.cn; Tel.: +86-0591-2286-6790

\begin{abstract}
In order to fabricate fibrous eutectic $\mathrm{Si}$, the selective etching of industrial $\mathrm{Al}-\mathrm{Si}$ eutectic alloys directionally solidified at different growth rates and modified by different amounts of Sr was studied. Flake eutectic and fibrous Si were obtained by selective etching of non-modified, Sr-modified or directionally solidified Al-Si eutectic alloys. The optimal amount of Sr for fabricating branching eutectic Si was $0.04-0.07 \%$. Through directional solidification with a high enough growth rate (more than $200 \mu \mathrm{m} / \mathrm{s}$ ), lamellar eutectic Si transforms to fibrous eutectic Si for use in non-modified Al-Si eutectic alloys. The potentiodynamic polarization and cyclic voltammetry methods were used to test the corrosion behavior of non-modified and Sr-modified Al-Si eutectic alloys. With a constant potential of $0.5 \mathrm{~V}$ in $\mathrm{HCl}$ solution, non-modified $\mathrm{Al}-\mathrm{Si}$ eutectic alloys displayed initial pitting corrosion and subsequent spalling corrosion, and $0.04 \%$ Sr-modified samples displayed uniform pitting corrosion. Compared with non-modified Al-Si eutectic alloys, Sr-modified samples displayed better corrosion resistance with lower current density and shallower pit depth during the same etching conditions.
\end{abstract}

Keywords: eutectic Si; Sr modification; directional solidification; selective etching

\section{Introduction}

Al-Si eutectic alloys are broadly used in the engineering field due to their low weight ratio, excellent corrosion resistance and cast ability. The mechanical properties of conventional cast Al-Si eutectic alloys are very poor due to the existence of lamellar eutectic silicon in the matrix [1-5]. Therefore, the element $\mathrm{Na}$ or the element $\mathrm{Sr}$ is usually used to modify the Al-Si eutectic in the process of casting production [6-12]. Since Pacz [13] invented the modification process of Al-Si alloys in 1927, many studies have researched the relationship between eutectic morphology and growth conditions [14-16]. Further, little work has focused on the effect of the amount of Sr added and the growth rate on directionally solidified Al-Si eutectic alloys. Another method to prompt the transition of flake to fibrous eutectic $\mathrm{Si}$ is rapid solidification with a high growth rate [17].

At present, mature preparation methods for silicon nanowires mainly include laser ablation [18], chemical vapor deposition [19], the oxide-assisted growth method [20], the template method [21], and the chemical corrosion method [22]. Combined selective dissolution with directional solidification was used by Hassel to fabricate metallic nanowires [23-25]. 
Fibrous eutectic Si was obtained by a selective etching of Sr-modified Al-Si eutectic alloys, and fibrous eutectic Si maybe a potential material in semiconductor field [10]. Al-Si eutectic alloys used in Hassel's work were smelted by pure $\mathrm{Al}$ and Si. However, in this work, industrial Al-Si eutectic alloys were used to reduce the cost of fabricating fibrous eutectic $\mathrm{Si}$ to promote fibrous eutectic $\mathrm{Si}$ use in the future in the semiconductor field. No studies have focused on the effect of $\mathrm{Sr}$ modification and rapid solidification on the morphology and microstructure of industrial $\mathrm{Al}-\mathrm{Si}$ eutectic alloys for fabricating fibrous eutectic $\mathrm{Si}$. Moreover, the effect of $\mathrm{Sr}$ addition on the corrosion behavior of industrial Al-Si eutectic alloys during the selective etching process is rarely considered.

In this work, the morphology and microstructure of directionally solidified Al-Si eutectic alloys modified by $\mathrm{Sr}$ at different growth rates were studied. The effect of $\mathrm{Sr}$ addition on the corrosion behavior of Al-Si eutectic alloys was considered. The selective etching process of the $\alpha-\mathrm{Al}$ matrix for fabricating fibrous eutectic $\mathrm{Si}$ in industrial $\mathrm{Al}-\mathrm{Si}$ eutectic alloys was also studied. This opens the door to low-cost fabrication and extraction of fibrous eutectic Si for use in future in the semiconductor field.

\section{Experimental}

The starting materials used in the experiments were industrial ZL102 Al-Si eutectic alloys. The alloy composition is shown in Table 1. Al-Si eutectic alloys were processed in a homemade directional solidification furnace at a heating temperature of $1000{ }^{\circ} \mathrm{C}$, a temperature gradient of approximately $5 \mathrm{~K} \mathrm{~cm}^{-1}$, and growth rates of 30, 50, 70, 100, 150, and $200 \mu \mathrm{m} \mathrm{s}^{-1}$. The element $\mathrm{Sr}$ was added in the form of the master alloy $\mathrm{Al}-10 \% \mathrm{Sr}$. Samples were heated to $760{ }^{\circ} \mathrm{C}$ in the crucible furnace. After holding at that temperature $30 \mathrm{~min}$, the temperature was reduced to $730^{\circ} \mathrm{C}$ and the samples were added at amounts of $0.01 \%, 0.04 \%, 0.07 \%$ and $0.1 \%$, respectively. Alloy liquids were mechanically stirred for $5 \mathrm{~min}$, then the temperature was reduced to $720^{\circ} \mathrm{C}$. Alloy liquids were held at that temperature for $30 \mathrm{~min}$ and then casted to samples.

Table 1. Alloy composition of industrial ZL102 Al-Si eutectic alloys.

\begin{tabular}{ccccccccccc}
\hline$\%$ & $\mathbf{S i}$ & $\mathbf{F e}$ & $\mathbf{C u}$ & $\mathbf{M n}$ & $\mathbf{M g}$ & $\mathbf{Z n}$ & Ti & Impurities & Allowance \\
\hline ZL102 & $10.0-10.3$ & $0.0-0.7$ & $\leq 0.3$ & $\leq 0.5$ & $\leq 0.1$ & $\leq 0.1$ & $\leq 0.2$ & $\leq 2.0$ & $\mathrm{Al}$ \\
\hline
\end{tabular}

The three-dimensional morphology of the samples was obtained by etching the samples in $1 \mathrm{M} \mathrm{HCl}$ at a constant potential of $0.5 \mathrm{~V}$ by an electrochemical workstation. A conventional three-compartment cell with working, reference, and counter electrodes was employed at room temperature. The reference electrode was a saturated calomel electrode, and platinum foil was adopted as the counter electrode. The directionally solidified Al-Si eutectic alloy test rod was connected to the sheets as the working electrode. The working and reference electrodes were connected by a Luggin capillary tube. The scanning speed of the potentiodynamic polarization curve is $0.5 \mathrm{mV} \cdot \mathrm{s}^{-1}$, and the scanning potential interval is $-2.0 \sim+0 \mathrm{~V}$ (vs. SCE). The scanning range of the cyclic voltammetry curve is $-0.5 \sim+0.2 \mathrm{~V}$ (vs. SCE), and the scanning speed is $40 \mathrm{mV} \cdot \mathrm{s}^{-1}$.

A high-precision desktop acidity meter (HANNA HI3221, Hanna, Padova, Italy) was used to measure the $\mathrm{pH}$ values in the etchants. An electrochemical workstation (CorrTest CS350, Wuhan Corrtest Instruments Corp., Ltd., Wuhan, China) was applied in the electrochemical measurements. The morphology of eutectic $\mathrm{Si}$ was observed by using a field emission scanning electron microscope (FESEM; Quanta 600FEG, FEI, Hillsboro, OR, USA) with energy-dispersive spectra (EDS) analysis.

\section{Results and Discussion}

Figure 1 shows the three-dimensional morphology of eutectic Si modified by different amounts of Sr after selective etching the $\alpha$-Al matrix. The $\alpha$-Al matrix was removed by etching the samples in $1 \mathrm{M} \mathrm{HCl}$ at a constant potential of $0.5 \mathrm{~V}$ for $4 \mathrm{~h}$. Optimum conditions 
for selective etching matrix were determined using Pourbaix diagrams of $\mathrm{Al}$ and $\mathrm{Si}$ [10]. For selective dissolution, the $\alpha$-Al matrix conditions were a pH above $0(1 \mathrm{M} \mathrm{HCl})$ and a potential of $0.5 \mathrm{~V}$. As shown in Figure 1, the $\alpha$-Al matrix was almost completely dissolved, and the eutectic Si was exposed. Eutectic Si has a thick sheet structure in non-modified Al-Si eutectic alloys (Figure 1a) [26]. When the addition amount of $\mathrm{Sr}$ is $0.01 \%$, a few short rods of eutectic $\mathrm{Si}$ are found on surface of the $\alpha$ - $\mathrm{Al}$ matrix (Figure 1b). Increasing the amount of Sr added to $0.04 \%$, significantly increases the number of fine short rod eutectic $\mathrm{Si}$ (Figure 1c). The optimal amount of $\mathrm{Sr}$ for fabricating long and branching eutectic $\mathrm{Si}$ from thick flake Si was $0.07 \%$. (Figure $1 \mathrm{~d}$ ). The numbers of branching eutectic Si are revealed on the surface of the $\alpha$-Al matrix. The diameter of the branching Si micro wires is approximately 100-200 $\mathrm{nm}$, and its length can reach dozens of microns. Combined with selective etching, Sr modification is a low-cost and efficient method for fabricating branching silicon micro-wires, and these micro-wires maybe have potential applications in semiconductor devices [10]. The optimal amount of $\mathrm{Sr}$ for fabricating branching eutectic $\mathrm{Si}$ was $0.04-0.07 \%$.

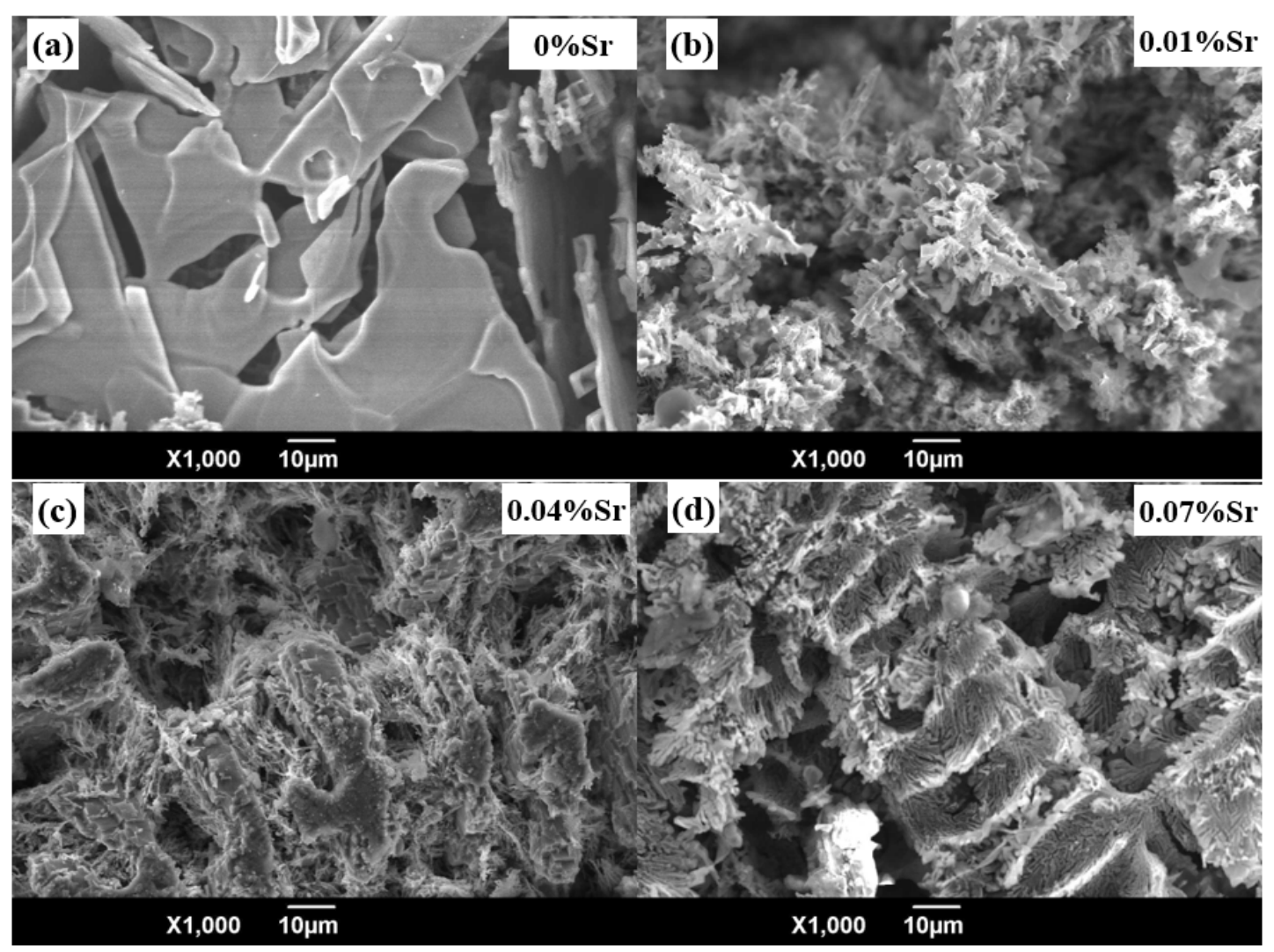

Figure 1. Eutectic Si morphology of Al-Si eutectic alloy modified by different amounts of Sr: (a) $0 \% \mathrm{Sr},(\mathbf{b}) 0.01 \% \mathrm{Sr}$, (c) $0.04 \%$ Sr, (d) $0.07 \%$ Sr.

According to the impurity-induced twinning mechanism (IIT), Sr adsorbs on the front of the growth interface of eutectic $\mathrm{Si}$, which hinders the growth of the original twin crystal step of the eutectic Si. This induces a large number of twin crystals, which results in the growth of eutectic $\mathrm{Si}$ changes from anisotropy to isotropy. Therefore, fibrous eutectic $\mathrm{Si}$ with a number branches is produced. EDS plane scanning in Figure 2 shows that the element $\mathrm{Sr}$ is almost uniformly distributed in eutectic Si. Additionally, micro X-ray fluorescence detection technology demonstrated the same phenomenon [27]. This verifies that the element $\mathrm{Sr}$ aggregates on the growth front interface of eutectic silicon and urges the transformation of lamellar to fibrous eutectic Si [28]. 

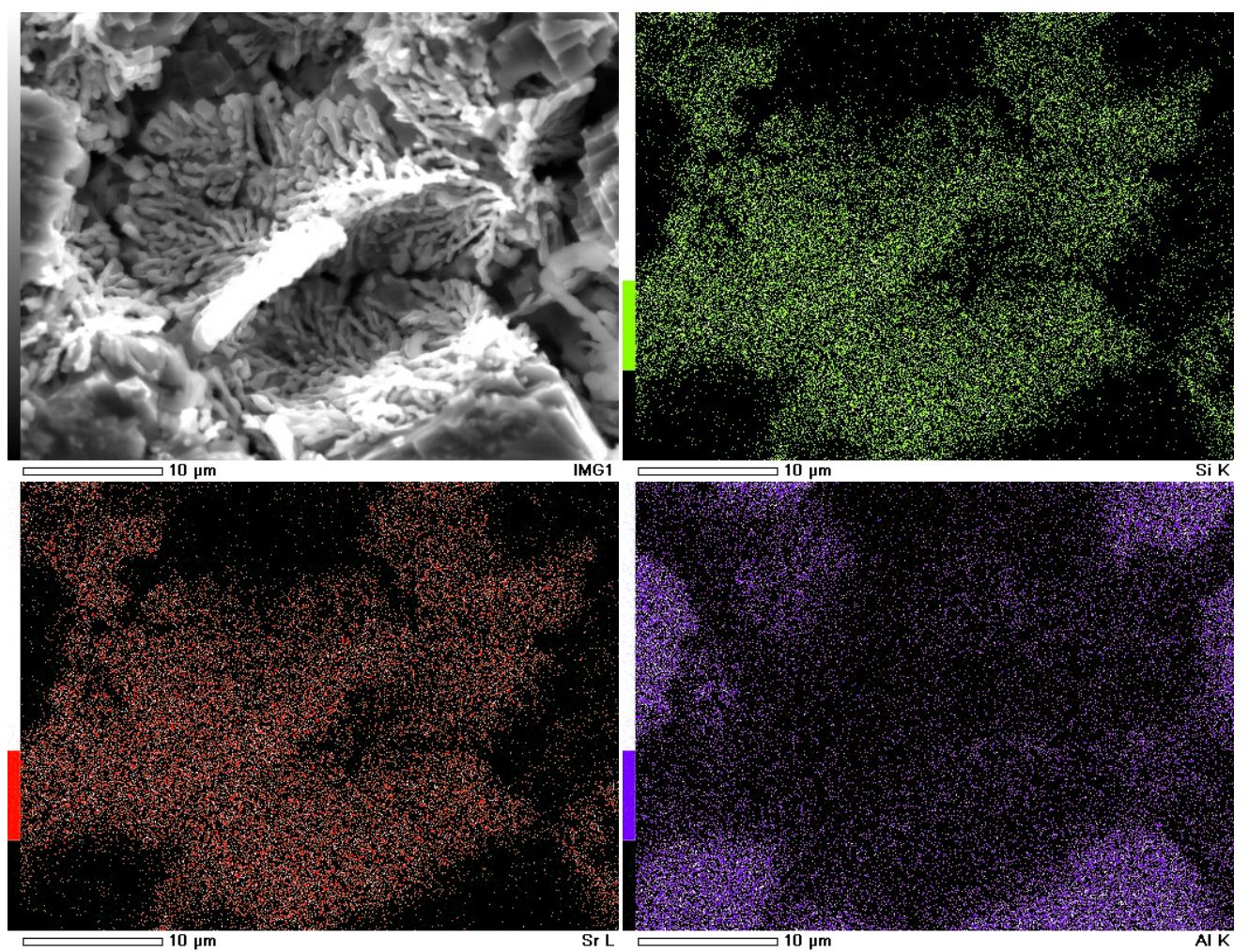

Figure 2. Morphology of eutectic Si after the Al-Si eutectic alloy is modified by $0.07 \% \mathrm{Sr}$ and the corresponding EDS plane scan map.

When the growth rate is $30 \mu \mathrm{m} / \mathrm{s}$, there are small branches at the end of some sheet eutectic silicon (Figure 3a). When at $70 \mu \mathrm{m} / \mathrm{s}$, the larger lamellar structure of eutectic silicon is obviously reduced, and the silicon wafer is finer. The size of large flake structure decreases and more bifurcations appear at the end of flake structure at the growth rate of $200 \mu \mathrm{m} / \mathrm{s}$ (Figure 3c). For those Sr-modified eutectic Si, branching Si micro-wires are found in the surface of the matrix. With the increase in growth rate, the size of Si micro-wires decreases and the length of branching increases. The evolving microstructure of nonmodified eutectic Si with increasing growth rate is the intrinsic growth mechanism. At the low growth rate, the growth mechanism of eutectic $\mathrm{Si}$ is controlled by the impurity-induced twinning mechanism, and displays a lamellar morphology (Figure 3a). When increasing the growth rate, the growth is becoming isotropic in the plane of the eutectic Si. This may conclude in the development and formation of the rod-like structures within the plane of the eutectic Si (Figure 3c). With a high enough growth rate, lamellar eutectic Si transforms to fibrous eutectic Si due to the low-speed in-plane growth to high-speed out-of-plane growth without Sr modification [17]. The transformation of sheet $\mathrm{Si}$ to fibrous $\mathrm{Si}$ is associated with dynamic undercooling in the high growth rate. The high growth rate results in a high growth dynamic undercooling of eutectic $\mathrm{Si}$, and this high dynamic undercooling leads to the unsteady growth of eutectic $\mathrm{Si}$ (Figure 3). This illustrates that eutectic Si micro-wires can be obtained by a high enough growth rate without $\mathrm{Sr}$ modification. 

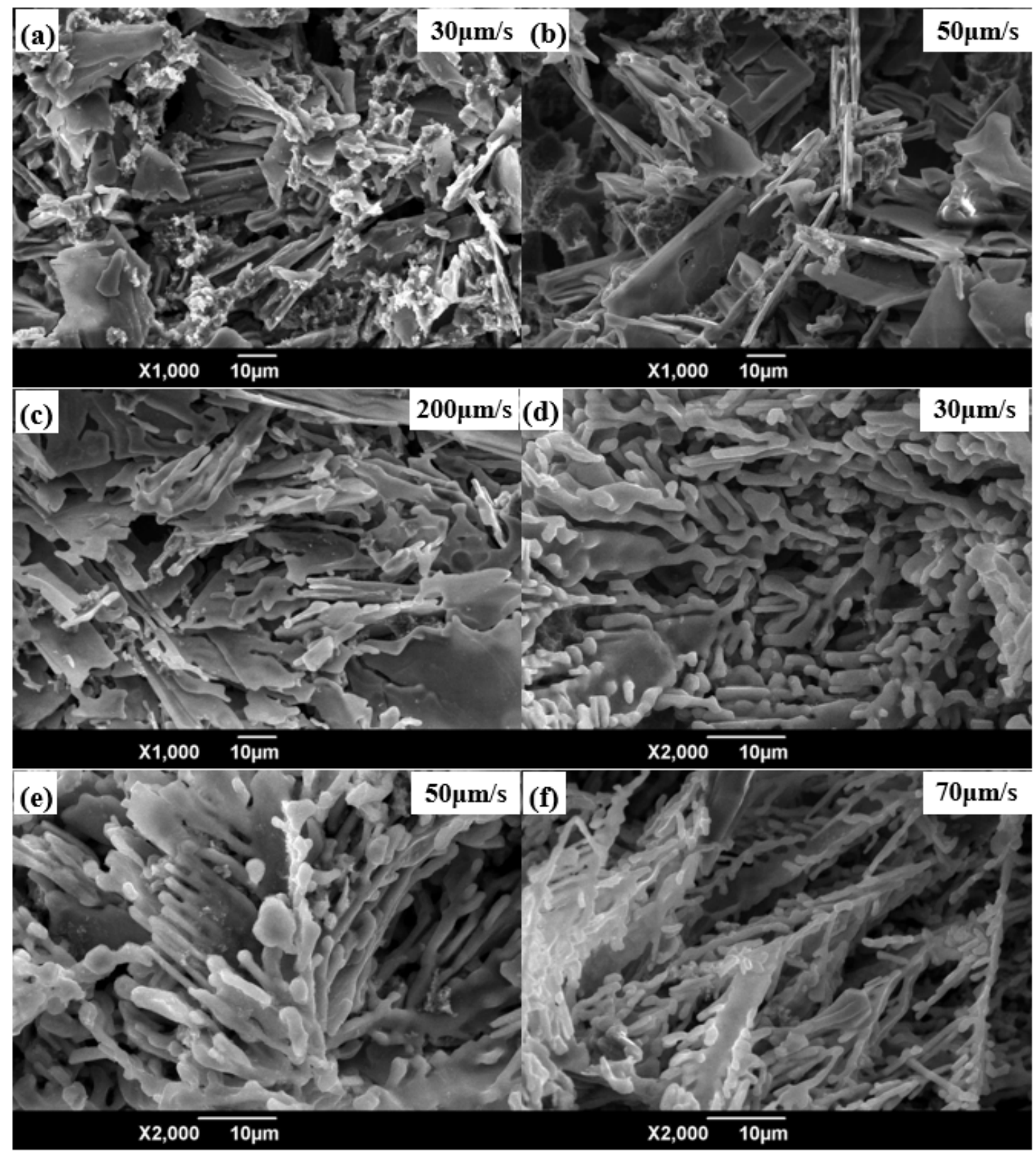

Figure 3. Morphology of eutectic Si in directional solidification of the Al-Si eutectic alloy at different growth rates and modified by different amounts of Sr. $0 \%$ Sr: $(\mathbf{a}-\mathbf{c}) ; 0.07 \%$ Sr: $(\mathbf{d}-\mathbf{f})$.

Figure 4 shows that the eutectic spacing $d$ and the size $a$ of the non-modified eutectic $S i$ vary with the growth rate $V$. Both the eutectic spacing and size of eutectic Si decrease with increasing growth rate. As illustrated in Figure 4, eutectic spacing and size are linearly related to the growth rate, and the linear fitting results are as follows: $a=10.13 V^{-0.38}$, $d=34.08 \mathrm{~V}^{-0.48}$, which satisfy the J-H model [29]. Both the eutectic spacing and the of eutectic $\mathrm{Si}$ also decrease with increasing growth rate for the Sr-modified eutectic $\mathrm{Si}$. As illustrated in Figures 5 and 6, eutectic spacing and size are linearly related to the growth rate, which also satisfy the $\mathrm{J}-\mathrm{H}$ model. 


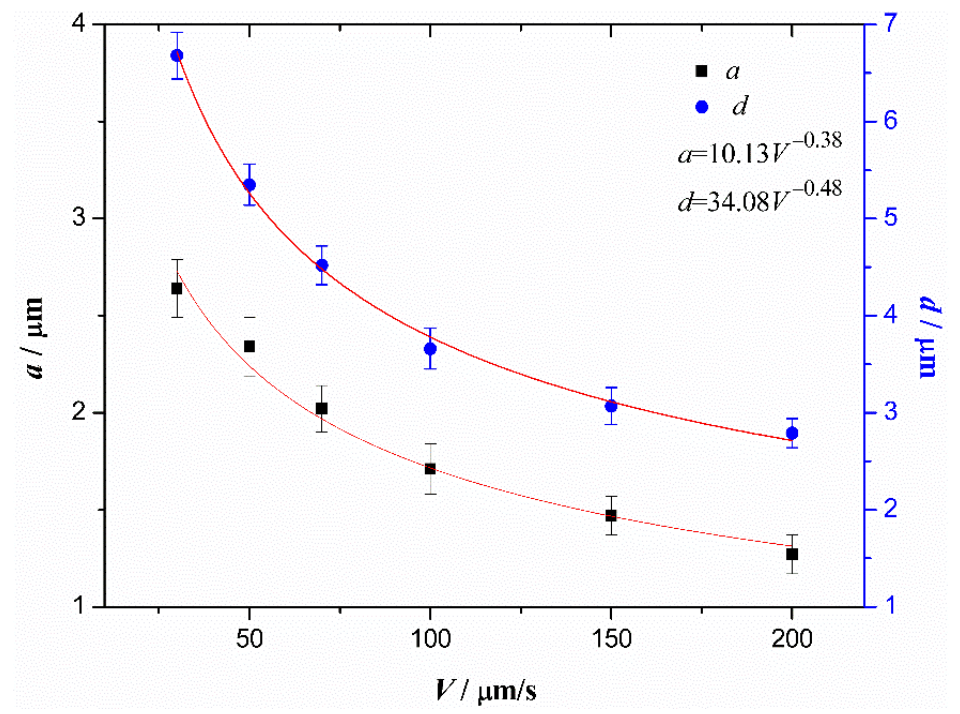

Figure 4. The eutectic spacing $d$ and the size $a$ of non-modified eutectic Si vary with the growth rate $V$.

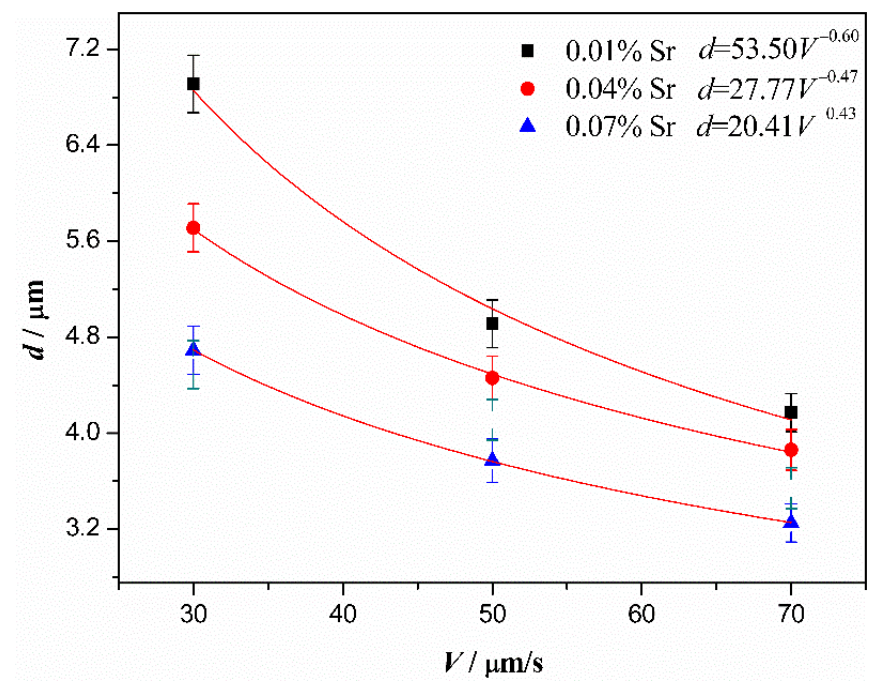

Figure 5. The eutectic spacing $d$ of modified eutectic Si varies with the growth rate $V$.

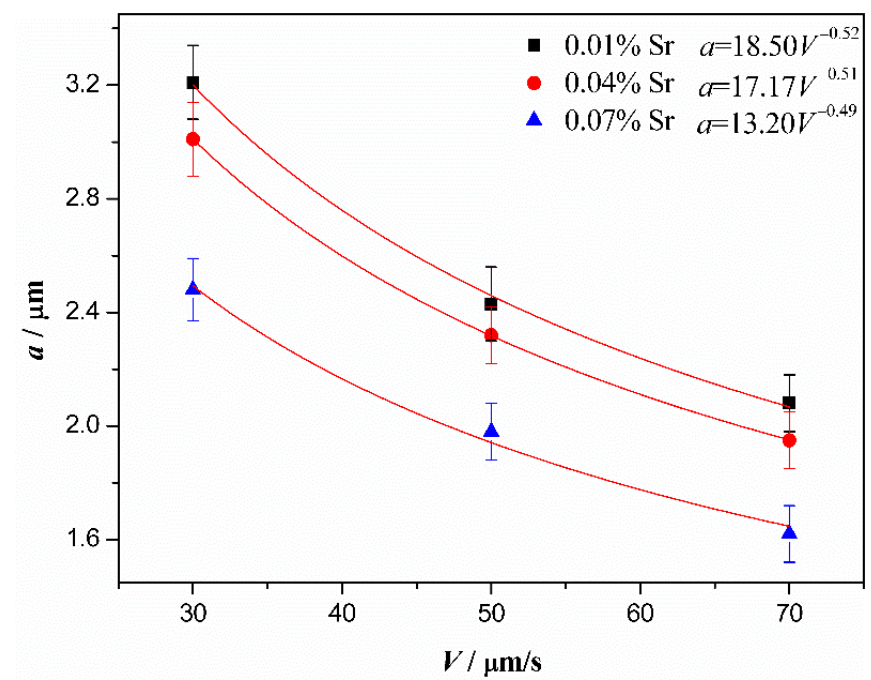

Figure 6. The eutectic spacing size $a$ of modified eutectic Si varies with the growth rate $V$. 
Figure 7 shows the morphology of non-modified Al-Si eutectic alloys etching at different times. When the etching time is $1 \mathrm{~h}$, a small amount of pitting pores are found in the surface of the matrix (Figure 7a). With the increase in corrosion time to $4 \mathrm{~h}$, pitting corrosion exacerbates and obvious crevice corrosions appear [30]. As the $\alpha$-Al matrix is etched and removed, the coarse lamellar eutectic silicon with a clear structure is revealed in the pitting pores (Figure $7 \mathrm{c}, \mathrm{d}$ ). With continued etching of the $\alpha$-Al matrix, greater amounts of eutectic Si fall into the etching solution. The coarse sheet eutectic silicon is obtained in the surface of the filter paper after $10 \mathrm{~h}$ of etching, as shown in Figure 7d. Clearly, sheet $\mathrm{Si}$ is not corroded by the process [10].
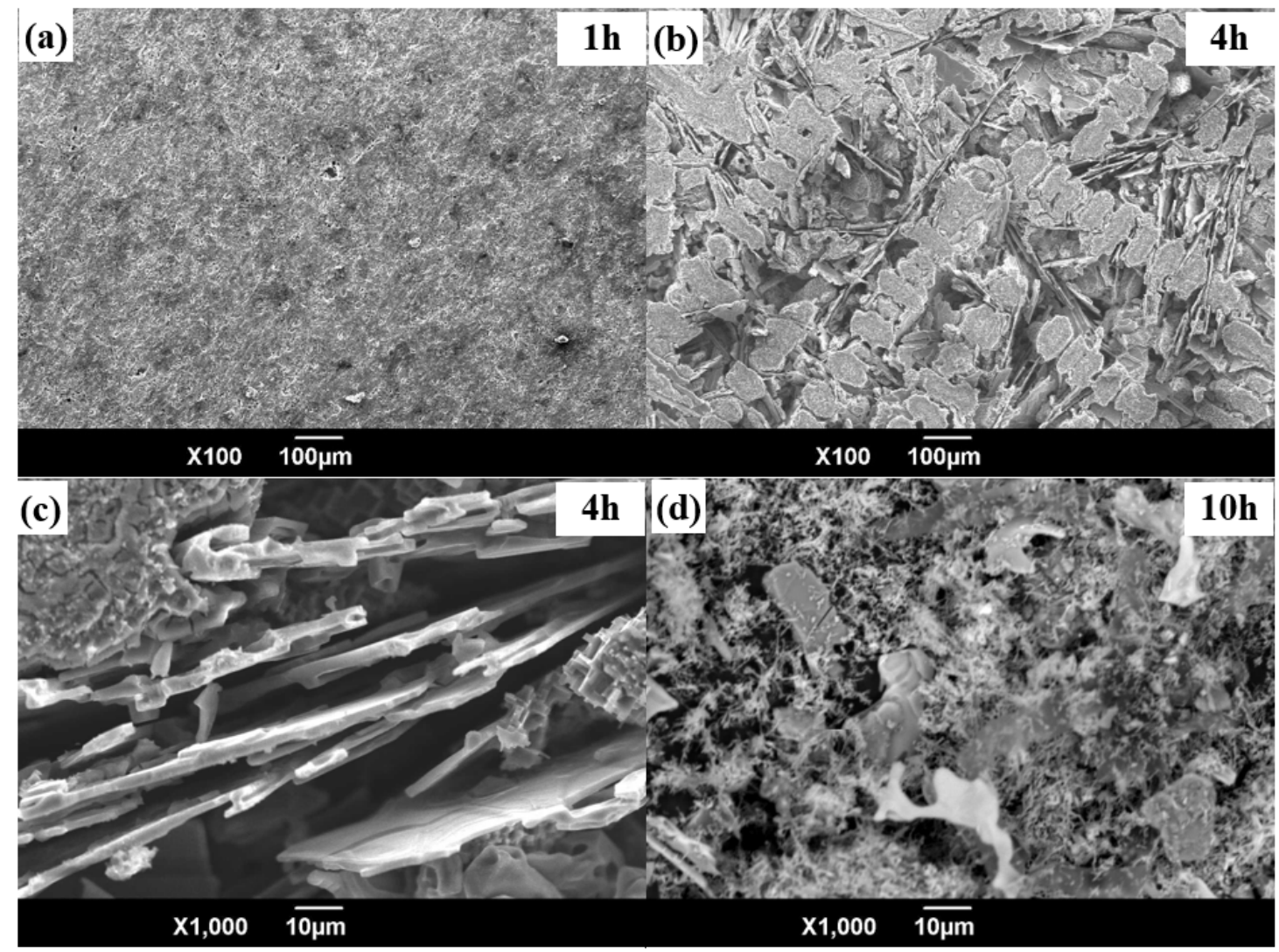

Figure 7. Non-modified Al-Si eutectic alloy etching at different etching times: (a) 1 h; (b,c) 4 h; (d) 10 h.

Figure 8 shows the morphology of $0.04 \%$ Sr-modified Al-Si eutectic alloy etching at different etching times. When the etching time is $1 \mathrm{~h}$, corrosion pits appear on the surface of Al-Si eutectic alloys. A number of eutectic Si micro-wires are found in the etching holes. When increasing the etching time to $4 \mathrm{~h}$, many deep corrosion holes are formed on the alloy surface due to the longitudinal deepening and expansion of pitting corrosion. There are a large number of silicon micro rods near the etching pit, which are disorderly distributed in micron $\alpha-\mathrm{Al}$ dendrites. At $10 \mathrm{~h}$, many dendritic micron $\alpha-\mathrm{Al}$ dendrites are corroded on the substrate surface, and many rectangular steps are exposed on the surface of $\alpha$-Al. A small amount of silicon micron rod insets the $\alpha$-Al dendrites. As shown in Figure 8, with a prolonged etching time, the Si micro-wires fall off the $\alpha$-Al dendrites due to the etching of the $\alpha$-Al matrix and the $\mathrm{H}_{2}$ scouring produced by the reaction. 


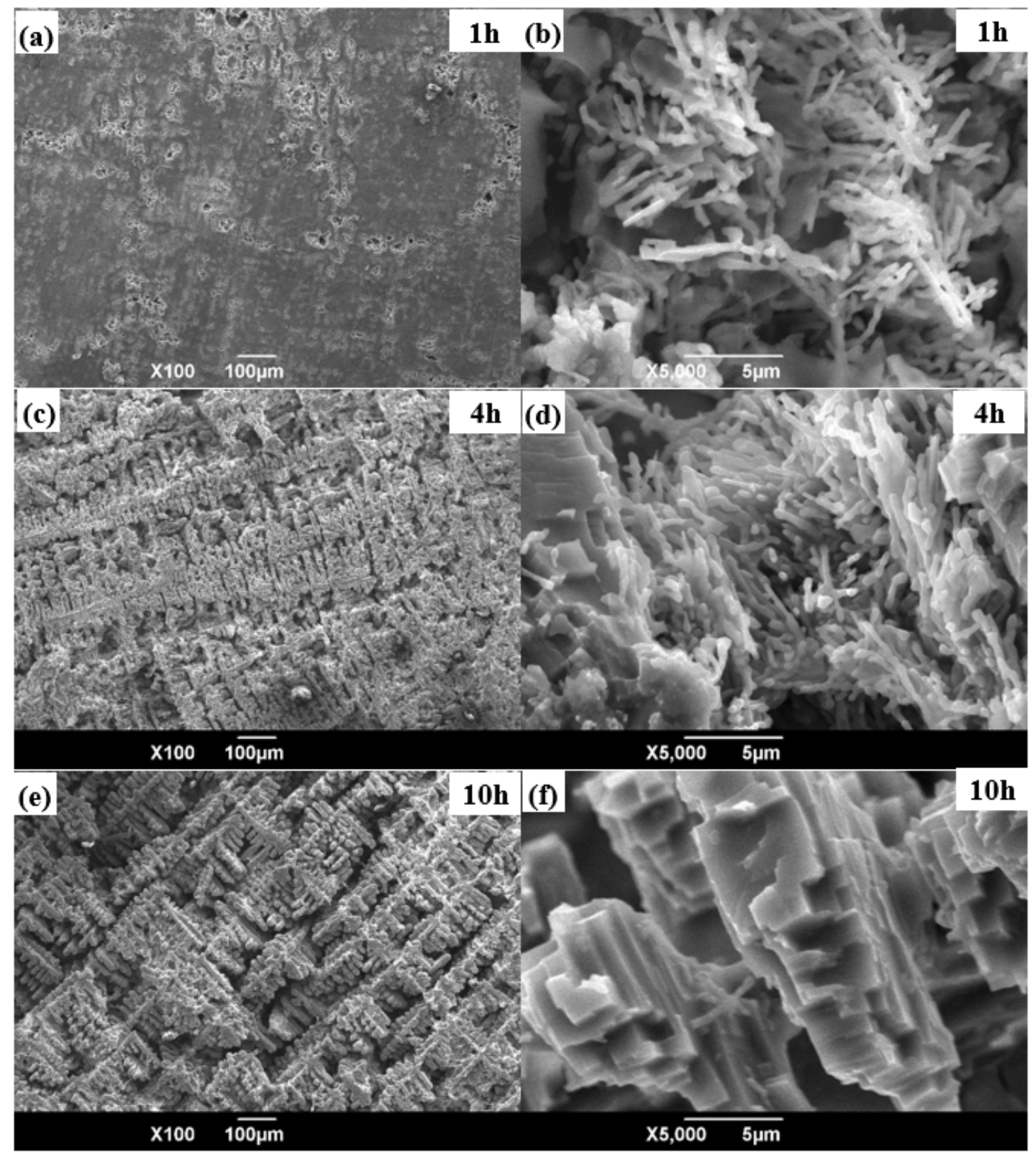

Figure 8. 0.04\% Sr-modified Al-Si eutectic alloy etching at different etching times: (a,b) 1 h; (c,d) 4 h; (e,f) 10 h.

The results of the polarization test for Al-Si eutectic alloys with different amounts of $\mathrm{Sr}$ are shown in Figure 9, which shows that the addition of Sr can change the corrosion resistance of Al-Si eutectic alloys. With an increase in $\mathrm{Sr}$, the polarization curves shift to negative, self-corrosion potential decreases, and self-corrosion tendency increases. Current density fluctuates in the anode branch with an increase in corrosion potential. The fluctuation in current density in the anode branch could be attributed to the action of pitting corrosion and the eutectic Si falls off the surface of the matrix. Corrosion current density and corrosion potential are given in Table 2. The corrosion current density of non-modified $\mathrm{Al}-\mathrm{Si}$ eutectic alloys is $0.475 \mathrm{~mA} \cdot \mathrm{cm}^{-2}$, and current density decreases to $8.26 \times 10^{-2} \mathrm{~mA} \cdot \mathrm{cm}^{-2}$ for the $0.04 \% \mathrm{Sr}$ samples. The corrosion resistance of aluminum alloy depends on the microstructure and precipitate phase [31,32]. The decrease in current density could be due to the transformation of sheet eutectic silicon into fibrous eutectic silicon (Figure 1). 


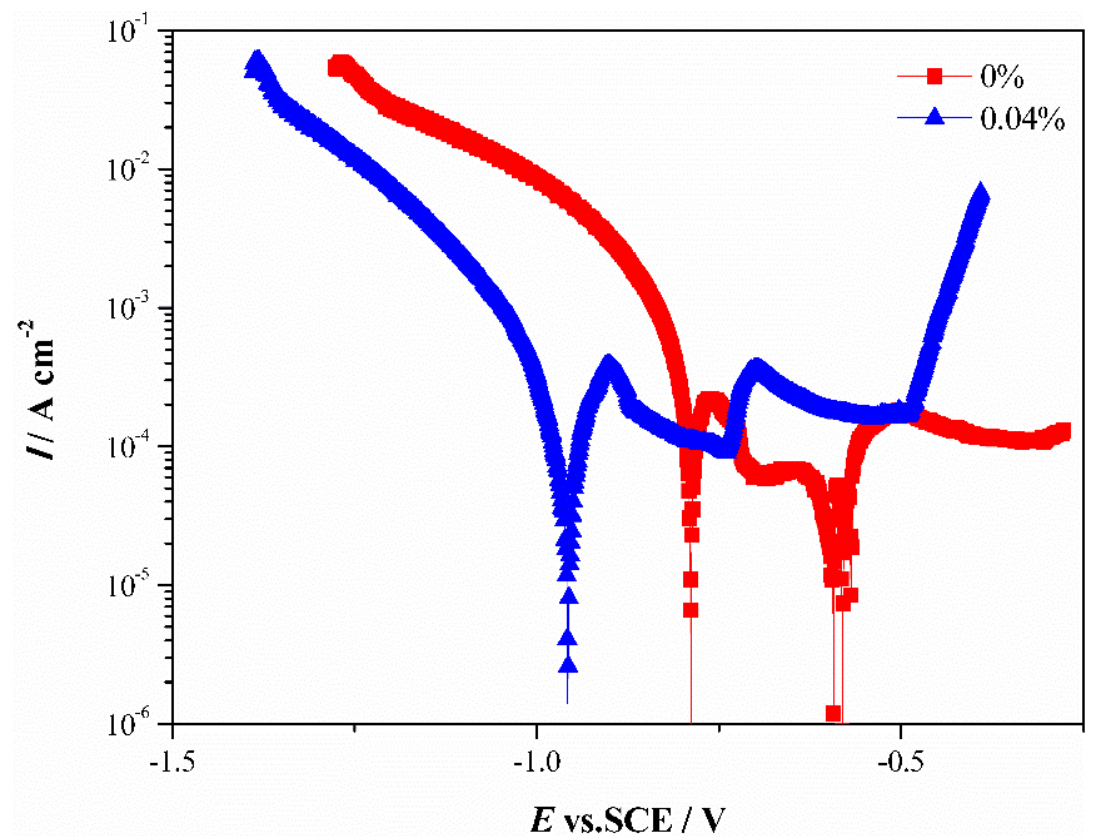

Figure 9. Potentiodynamic polarization curves for Al-Si eutectic alloys with different amounts of $\mathrm{Sr}$ in $0.1 \mathrm{M} \mathrm{HCl}$ solution.

Table 2. Polarization data of Al-Si eutectic alloys modified by different amounts of Sr in $0.1 \mathrm{M} \mathrm{HCl}$ solution.

\begin{tabular}{ccc}
\hline Sr contents $(\mathbf{w t})$ & $E_{\text {corr }} / \mathbf{V}$ (vs. SCE) & $I_{\text {corr }} /\left(\mathbf{m A} \cdot \mathbf{c m}^{-2}\right)$ \\
\hline $0 \%$ & -0.79 & 0.475 \\
$0.04 \%$ & -0.96 & $8.26 \times 10^{-2}$ \\
\hline
\end{tabular}

Figure 10 shows cyclic voltammetry curves for $0 \% \mathrm{Sr}$ and $0.04 \%$ Sr-modified Al-Si eutectic alloys in $0.1 \mathrm{M} \mathrm{HCl}$ solution. When scanning the potential from the negative value to the positive value, a large current peak appears at $-0.31 \mathrm{~V}$ for the $0.04 \%$ Sr-modified $\mathrm{Al}-\mathrm{Si}$ eutectic alloys, which is attributed to the oxidation of the element Al. However, for non-modified samples, the oxidation peak is at $-0.26 \mathrm{~V}$. When the anodic potential exceeds a certain value, the current rises suddenly to a very high value, suggesting breakdown of the passive film and initiation of pitting corrosion [33]. The breakdown of the passive film can be ascribed to the adsorption of the chloride ion on the passive film [34]. The pitting corrosion beyond pitting potential is confirmed by the SEM image of the matrix surface before and after its polarization at $0.5 \mathrm{~V}$ in a $0.1 \mathrm{M} \mathrm{HCl}$ solution (Figure 8a). In reverse scanning, a reduced peak is observed at $-0.37 \mathrm{~V}$, which may be related to the reduction of $\mathrm{H}^{+}$into $\mathrm{H}_{2}$ for the $0.04 \%$ Sr-modified samples, while the reduction peak is at $-0.32 \mathrm{~V}$ for non-modified samples. There is a decrease in current density at $-0.50 \mathrm{~V}$ for both the non-modified and $0.04 \%$ Sr-modified samples. This illustrates that the pitting potential is at approximately $-0.50 \mathrm{~V}$, which is consistent with the results of Hasssan [33]. 


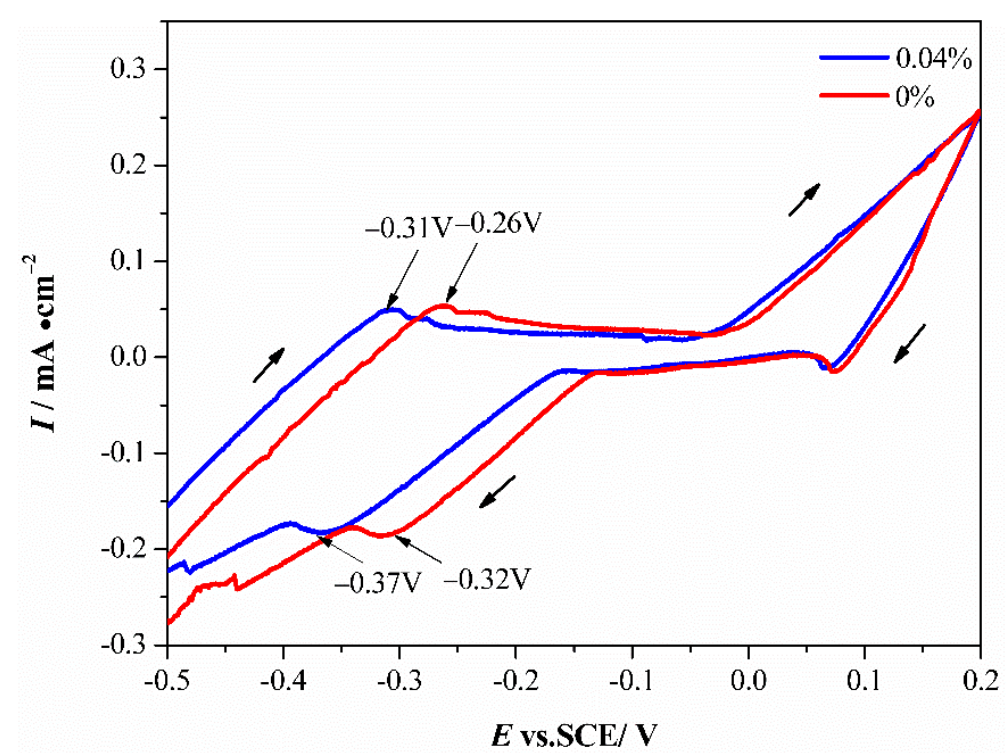

Figure 10. Cyclic voltammetry curves for $0 \% \mathrm{Sr}$ and $0.04 \%$ Sr-modified Al-Si eutectic alloys in $0.1 \mathrm{M}$ $\mathrm{HCl}$ solution.

Figure 11 shows the current-time curves for $0 \% \mathrm{Sr}$ and $0.04 \% \mathrm{Sr}$-modified $\mathrm{Al}-\mathrm{Si}$ eutectic alloys. The current density of non-modified and $0.04 \% \mathrm{Sr}$-modified samples are between 28 and $35 \mathrm{~mA} \cdot \mathrm{cm}^{-2}$. For non-modified Al-Si eutectic alloys, current density increases with prolonged etching time and sharply declines at approximately $200 \mathrm{~s}$. The increase in current density is due to the continued etching of the $\alpha$-Al matrix. The local sharp decrease in current density is associated with the exfoliation of coarse lamellar eutectic silicon from the $\alpha$-Al matrix. At the initial stage, the structure of the pitting pores is unstable and is in a metastable state. The $\mathrm{Cl}^{-}$ion attacks the alumina film in a continuous acidification process in the pitting pores. The $\mathrm{Cl}^{-}$ion adsorbs and transfers to the aluminum film, then it destroys the film at the film-metal interface and etches the $\alpha$-Al matrix around the eutectic silicon. Compared with non-modified samples, the current density of $0.04 \%$ Sr-modified samples is more stable with prolonged etching time. With a constant potential of $0.5 \mathrm{~V}$, the current density of non-modified samples is maintained at approximately $33.5 \mathrm{~mA} \cdot \mathrm{cm}^{-2}$, while that of $0.04 \% \mathrm{Sr}$-modified samples is maintained at approximately $31.2 \mathrm{~mA} \cdot \mathrm{cm}^{-2}$. Therefore, non-modified samples displayed initial pitting corrosion and subsequent spalling corrosion (Figure 7). The $0.04 \% \mathrm{Sr}$-modified samples prefer uniform pitting corrosion (Figure 8).

The oxidation and etching of the $\alpha$-Al matrix are according to the following:

$$
\begin{aligned}
& 2 \mathrm{Al}+3 \mathrm{H}_{2} \mathrm{O} \rightarrow \mathrm{Al}_{2} \mathrm{O}_{3}+3 \mathrm{H}_{2} \uparrow \\
& \mathrm{Al}_{2} \mathrm{O}_{3}+6 \mathrm{H}^{+} \rightarrow 2 \mathrm{Al}^{3+}+3 \mathrm{H}_{2} \mathrm{O}
\end{aligned}
$$

After the development of pitting corrosion, pitting corrosion develops into intergranular corrosion (Figures $7 \mathrm{~b}$ and $8 \mathrm{a}$ ). When the well-structured eutectic falls off the $\alpha$-Al matrix, current density fluctuates (Figure 11).

The current density of pitting corrosion can be described by [35]:

$$
i_{p i t}=\frac{n F D_{\mathrm{Al}^{3+}}\left(C_{\mathrm{Al}^{3+}}-C_{\mathrm{Al}^{3+}}^{\prime}\right)}{d_{\text {pit }}\left(1-t_{+}\right)}
$$

where $i_{\text {pit }}$ is current density, $n$ is the valence of the metal dissolution reaction, $F$ is Faraday's constant, $D_{\mathrm{Al}^{3+}}$ is the diffusivity of the metal cation, $C_{\mathrm{Al}^{3+}}$ is the concentration of $\mathrm{Al}^{3+}$ at the pit bottom, $\mathrm{C}_{\mathrm{Al}^{3+}}$ is the concentration of $\mathrm{Al}^{3+}$ in the bulk solution, $d_{\text {pit }}$ is the pit depth, 
and $t_{+}$is the transference number for $\mathrm{Al}^{3+}$ cations. Using current density in Figure 11, assuming $n=2.9, \mathrm{C}_{\mathrm{Al}^{3+}}=2.9 \mathrm{M}, t_{+}=0.45, \mathrm{C}_{\mathrm{Al}^{3+}}=0$ and $D_{\mathrm{Al}^{3+}}=3.5 \times 10^{-7} \mathrm{~cm}^{2} / \mathrm{s} \mathrm{[36]}$. The calculated $d_{\text {pit }}$ of non-modified sample is $15.39 \mu \mathrm{m}$, while that of the $0.04 \%$ Sr-modified sample is approximately $16.52 \mu \mathrm{m}$. The calculated pit length in this work is higher than Lucente's work (at $5 \mu \mathrm{m}$ ), and this may be due to the differences in the material structure, composition and etching condition of the samples. Sr-modified samples show a lower current density and pitting depth compared with non-modified samples.

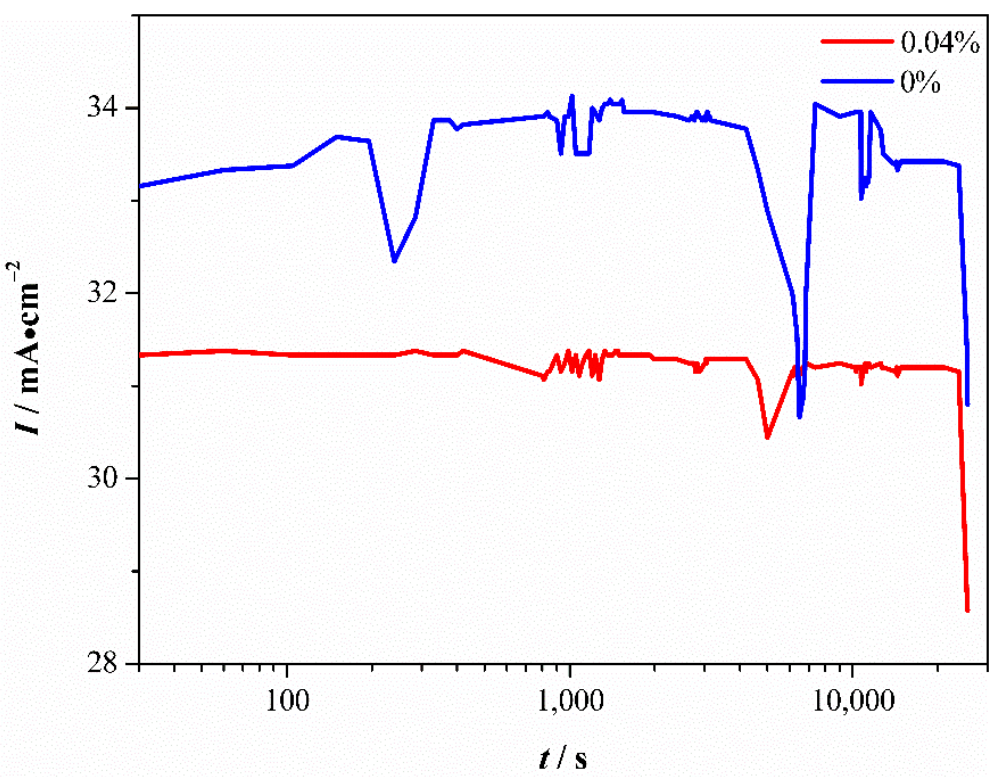

Figure 11. Current-time curves for $0 \% \mathrm{Sr}$ and $0.04 \%$ Sr-modified Al-Si eutectic alloys in $1.0 \mathrm{M} \mathrm{HCl}$ solution at a corrosion potential of $0.5 \mathrm{~V}$.

\section{Conclusions}

Flake and fibrous eutectic Si were fabricated by a selective etching of the $\alpha$-Al matrix in non-modified and Sr-modified Al-Si eutectic alloys, respectively. The following conclusions were drawn:

(1) The optimal amount of $\mathrm{Sr}$ for fabricating fibrous eutectic $\mathrm{Si}$ was $0.04-0.07 \%$. Sr adsorbed on the front of the growth interface of eutectic $\mathrm{Si}$, and hindered the growth of the original twin crystal step, which resulted in the growth of eutectic Si changes from anisotropy to isotropy. Therefore, fibrous eutectic $\mathrm{Si}$ with a number of branches was produced in Sr-modified Al-Si eutectic alloys.

(2) Transformation of lamellar eutectic Si to fibrous eutectic Si could be realized by high rapid solidification with a high enough growth rate (more than $200 \mu \mathrm{m} / \mathrm{s}$ ) for nonmodified Al-Si eutectic alloys. Both eutectic spacing and size decrease with increasing growth rate for Sr-modified and non-modified eutectic Si.

(3) With a constant potential of $0.5 \mathrm{~V}$ in $\mathrm{HCl}$ solution, non-modified Al-Si eutectic alloys displayed initial pitting corrosion and subsequent spalling corrosion, and $0.04 \% \mathrm{Sr}$ modified samples preferred uniform pitting corrosion. Compared with non-modified $\mathrm{Al}-\mathrm{Si}$ eutectic alloys, Sr-modified samples show better corrosion resistance with lower current density and shallower pitting depth due to Sr modification of eutectic Si.

Author Contributions: Conceptualization, J.G. and Z.Z.; methodology, J.Z.; formal analysis, H.G.; investigation, F.Z.; data curation, W.G.; writing-original draft preparation, J.G.; writing-review and editing, Z.Z. and L.Y.; visualization, J.W.; funding acquisition, J.G. and J.Z. All authors have read and agreed to the published version of the manuscript. 
Funding: This work is financially supported by [National Natural Science Foundation of China] grant number [51905103] and [Open project of State Key Laboratory of Advanced Welding and Joining] grant number [AWJ-21M23]. The project also is supported by [Natural Science Foundation of Fujian Province of China] grant number [2019J01211].

Data Availability Statement: Not applicable.

Conflicts of Interest: The authors declared that they have no conflict of interest to this work.

\section{References}

1. Lien, H.H.; Mazumder, J.; Wang, J.; Misra, A. Microstructure evolution and high density of nanotwinned ultrafine Si in hypereutectic Al-Si alloy by laser surface remelting. Mater. Charact. 2020, 161, 110147. [CrossRef]

2. Uludağ, M. Influence of Al-B grain refiner on porosity formation of directionally solidified Al-Si alloys. China Foundry 2020, 17, 372-377. [CrossRef]

3. Pereira, C.L.; Gomes, L.F.; Garcia, A.; Spinelli, J.E. Comparing the roles of Sb and Bi on microstructures and application properties of the Al-15\% Si alloy. J. Alloys Compd. 2021, 878, 160343. [CrossRef]

4. Hegde, S.; Prabhu, K.N. Modification of eutectic silicon in Al-Si alloys. J. Mater. Sci. 2008, 43, 3009-3027. [CrossRef]

5. Dahle, A.K.; Nogita, K.; McDonald, S.D.; Dinnis, C.; Lu, L. Eutectic modification and microstructure development in Al-Si Alloys. Mater. Sci. Eng. A 2005, 413, 243-248. [CrossRef]

6. Hafiz, M.F.; Kobayashi, T. Mechanical properties of modified and nonmodified eutectic Al-Si alloys. J. Jpn. Inst. Light Met. 1994, 44, 28-34. [CrossRef]

7. Gursoy, O.; Timelli, G. Lanthanides: A focused review of eutectic modification in hypoeutectic Al-Si alloys. J. Mater. Res. Technol. 2020, 9, 8652-8666. [CrossRef]

8. Barrirero, J.; Pauly, C.; Engstler, M.; Ghanbaja, J.; Ghafoor, N.; Li, J.; Schumacher, P.; Odén, M.; Mücklich, F. Eutectic modification by ternary compound cluster formation in Al-Si alloys. Sci. Rep. 2019, 9, 5506. [CrossRef]

9. Çolak, M. Modification of eutectic Al-Si alloys by Sr and CuSn 5 . Mater. Res. Express 2019, 6, 1065a2. [CrossRef]

10. Milenkovic, S.; Dalbert, V.; Marinkovic, R.; Hassel, A.W. Selective matrix dissolution in an Al-Si eutectic. Corros. Sci. 2009, 51, 1490-1495. [CrossRef]

11. Sens, H.; Eustathopoulos, N.; Camel, D.; Favier, J. Solidification of binary and Sr-modified Al-Si eutectic alloys: Theoretical analysis of solute fields. Acta Met. Mater. 1992, 40, 1783-1789. [CrossRef]

12. Campbell, J. Discussion of "Effect of Strontium and Phosphorus on Eutectic Al-Si Nucleation and Formation of $\beta$-Al ${ }_{5}$ FeSi in Hypoeutectic Al-Si Foundry Alloys". Metall. Mater. Trans. A 2009, 40, 1009-1010. [CrossRef]

13. Pacz, A. Alloy. U.S. Patent No. 1387900, 13 February 1920. Available online: https://patents.google.com/patent/US1387900A/en (accessed on 30 November 2021).

14. Lu, S.Z.; Hellawell, A. The mechanism of silicon modification in aluminum-slicon alloys: Impurity induced twinning. Metall. Mater. Trans. 1987, 18, 1721-1733. [CrossRef]

15. Lu, S.Z.; Hellawell, A. Modification of Al-Si alloys: Microstructure, thermal analysis, and mechanisms. JOM 1995, 47, 38-40. [CrossRef]

16. Hogan, L.M.; Kobayashi, K.F.; Shamsuzzoha, M. Discussion of "the mechanism of silicon modification in aluminum-silicon alloys: Impurity-induced twinning". Metall. Trans. A 1989, 20, 1286-1288. [CrossRef]

17. Hosch, T.; England, L.G.; Napolitano, R.E. Analysis of the high growth-rate transition in Al-Si eutectic solidification. J. Mater. Sci. 2009, 44, 4892-4899. [CrossRef]

18. Zabotnov, S.V.; Skobelkina, A.V.; Sergeeva, E.A.; Kurakina, D.A.; Khilov, A.V.; Kashaev, F.V.; Kaminskaya, T.P.; Presnov, D.E.; Agrba, P.D.; Shuleiko, D.V.; et al. Nanoparticles Produced via Laser Ablation of Porous Silicon and Silicon Nanowires for Optical Bioimaging. Sensors 2020, 20, 4874. [CrossRef] [PubMed]

19. Hu, D.; Xiang, J.; Zhou, Q.; Su, S.; Zhang, Z.; Wang, X.; Jin, M.; Nian, L.; Nözel, R.; Zhou, G.; et al. One-step chemical vapor deposition of $\mathrm{MoS}_{2}$ nanosheets on SiNWs as photocathodes for efficient and stable solar-driven hydrogen production. Nanoscale 2018, 10, 3518-3525. [CrossRef]

20. Jiang, B.; Liao, F.; Sun, Y.; Cheng, Y.; Shao, M. Pt nanocrystals on nitrogen-doped graphene for the hydrogen evolution reaction using Si nanowires as a sacrificial template. Nanoscale 2017, 9, 10138-10144. [CrossRef]

21. Nehra, M.; Dilbaghi, N.; Marrazza, G.; Kaushik, A.; Abolhassani, R.; Mishra, Y.K.; Kim, K.H.; Kumar, S. 1D semiconductor nanowires for energy conversion, harvesting and storage applications. Nano Energy 2020, 76, 104991. [CrossRef]

22. Hu, Y.; Jin, C.; Liu, Y.; Yang, X.; Liao, Z.; Zhang, B.; Zhou, Y.; Chen, A.; Wu, L.; Liu, J.; et al. Metal Particle Evolution Behavior during Metal Assisted Chemical Etching of Silicon. ECS J. Solid State Sci. Technol. 2021, 10, 084002. [CrossRef]

23. Milenkovic, S.; Schneider, A.; Frommeyer, G. Constitutional and microstructural investigation of the pseudobinary NiAl-W system. Intermetallics 2011, 19, 342-349. [CrossRef]

24. Joslin, S.M.; Chen, X.F.; Oliver, B.F.; Noebe, R. Fracture behavior of directionally solidified NiAl-Mo and NiAl-V eutectics. Mater. Sci. Eng. A 1995, 196, 9-18. [CrossRef]

25. Milenkovic, S.; Hassel, A.W.; Schneider, A. Effect of the growth conditions on the spatial features of Re nanowires produced by directional solidification. Nano Lett. 2006, 6, 794-799. [CrossRef] [PubMed] 
26. Shankar, S.; Riddle, E.Y.; Makhloufm, M. Eutectic solidification of aluminum-silicon alloys. Metall. Mater. Trans. A 2004, 35, 3038-3043. [CrossRef]

27. Nogita, K.; Yasuda, H.; Yoshida, K.; Uesugi, K.; Takeuchi, A.; Suzuki, Y.; Dahle, A. Determination of strontium segregation in modified hypoeutectic Al-Si alloy by micro X-ray fluorescence analysis. Scr. Mater. 2006, 55, 787-790. [CrossRef]

28. Barrirero, J.; Engstler, M.; Ghafoor, N.; de Jonge, N.; Odén, M.; Mücklich, F. Comparison of segregations formed in unmodified and Sr-modified Al-Si alloys studied by atom probe tomography and transmission electron microscopy. J. Alloys Compd. 2014, 611, 410-421. [CrossRef]

29. Jackson, K.A.; Hunt, J.D. Lamellar and rod eutectic growth. Trans. AIME 1966, 236, 1129-1141.

30. Zor, S.; Zeren, M.; Ozkazanc, H.; Karakulak, E. Effect of Cu Content on Corrosion of Al-Si Eutectic Alloys in Acidic Solutions. Anti-Corros. Methods Mater. 2010, 57, 185-191. [CrossRef]

31. Zeng, F.; Wei, Z.; Li, J.; Li, C.; Tan, X.; Zhang, Z.; Zheng, Z. Corrosion mechanism associated with Mg ${ }_{2} \mathrm{Si}$ and Si particles in Al-Mg-Si alloys. Trans. Nonferr. Met. Soc. China 2011, 21, 2559-2567. [CrossRef]

32. Ahlatci, H. Production and corrosion behaviours of the Al-12Si-XMg alloys containing in situ $\mathrm{Mg}_{2} \mathrm{Si}$ particles. J. Alloys Compd. 2010, 503, 122-126. [CrossRef]

33. Hassan, H.H.; Fahmy, K. Pitting Corrosion of Tin by Acetate Anion in Acidic Media. Int. J. Electrochem. Sci. 2008, 3, $29-43$.

34. Vračar, L.; Dražić, D.M. Influence of chloride ion adsorption on hydrogen evolution reaction on iron. J. Electroanal. Chem. 1992, 339, 269-279. [CrossRef]

35. Lucente, A.M.; Scully, J.R. Localized Corrosion of Al-Based Amorphous-Nanocrystalline Alloys with Solute-Lean Nanocrystals: Pit Stabilization. J. Electrochem. Soc. 2008, 155, C234-C243. [CrossRef]

36. Beck, T.R. Salt film formation during corrosion of aluminum. Electrochim. Acta 1984, 29, 485-491. [CrossRef] 